\title{
Systems Analysis of Vulnerability to Hydrometeorological Threats: An Exploratory Study of Vulnerability Drivers in Northern Zimbabwe
}

\author{
Emmanuel Mavhura ${ }^{1}$
}

Published online: 30 April 2019

(C) The Author(s) 2019

\begin{abstract}
Disasters result from complex interactions of hazards and vulnerability conditions. Reducing human exposure and sensitivity to threats can reduce disaster impact. Prior knowledge about community vulnerability levels is crucial to minimizing potential losses from future threats. Most vulnerability studies focus on high-impact disasters and their temporal and spatial analyses. Yet highfrequency, low-impact disasters have a cumulative potential to severely disrupt or damage socioeconomic systems. There is limited knowledge especially in the global south about the creation of vulnerability to hydrometeorological threats. Using a systems approach, this study explores ways in which communities in the northern semiarid tropics of Zimbabwe are vulnerable to hydrometeorological threats. This predominantly qualitative study used literature review, interviews, transect walks, and focus groups to gather data from selected samples involving smallholder farmers with in-depth knowledge about community vulnerability. The results show that the communities are vulnerable to multiple hydrometeorological threats due to multiple interacting factors including rainfed and floodbased farming, land tenure, topography, climate, and other socioeconomic conditions such as inadequate income sources and high poverty. In order to reduce vulnerability, this study provides five policy options for government and nongovernmental organization interventions, including the need to transform rural economies beyond the traditional rainfed and flood-based farming systems.
\end{abstract}

Emmanuel Mavhura

edmavhura@gmail.com; emavhura@buse.ac.zw

1 Department of Geography, Bindura University of Science Education, Bindura, Zimbabwe
Keywords Community vulnerability $\cdot$ Flood-based farming $\cdot$ Hydrometeorological threats $\cdot$ Rainfed agriculture $\cdot$ Zimbabwe

\section{Introduction}

The term disaster is conceptualized as an event concentrated in time and space, during which a social system undergoes severe losses to an extent that the fulfilment of its essential functions is prevented or disrupted (Chen et al. 2012). One of the most important issues in understanding disasters is that natural processes are not their only causes. Rather disasters are a product of "social, political and economic environments (as distinct from the natural causes) that structure the lives of different groups of people" (Wisner et al. 2004, p. 4). Disasters result from insufficient capacity to reduce the potential negative impacts of hazards. This perspective involves varying magnitudes of vulnerability: some groups of people suffer increased damage and loss when faced with similar shocks and stressors. The differences in capacity can explain why societies with similar levels of exposure may be impacted differently by a particular hazard (Cutter et al. 2009; Finch et al. 2010).

Vulnerability is a term that is widely used in the physical and social sciences. As a result, a dozen scholarly definitions of vulnerability have emerged across disciplines and practices (Kelman et al. 2016; Mavhura 2018). In an effort to promote a common understanding of vulnerability, the United Nations International Strategy for Disaster Reduction defines vulnerability as the characteristics and circumstances of a community, system, or asset that make it susceptible to the damaging effects of a hazard (UNISDR 2004; United Nations 2016). According to this perspective, 
vulnerability is the degree to which a system reacts adversely to actual or perceived threats (Gain et al. 2015). This makes vulnerability essentially a state variable, which is determined by the internal properties of a system. A combination of physical forces and socioeconomic processes of the human-environment system usually determine vulnerability (Kusenbach et al. 2010). The basic question underlying vulnerability analysis is how natural hazards affect a society. To answer this question, Armas and Gavriş (2013) view vulnerability as a major determinant of disasters rather than the hazards themselves. This is because a hazard on its own cannot produce a disaster unless it interacts with people and their infrastructure. If a river runs over its banks, for example, it is not a disaster per se because it is just a natural process. The natural process becomes a disaster if human beings, infrastructure, or other forms of capital are threatened (Raschky 2008). Whether this natural process evolves into a disaster, or not, is not solely in the realm of the natural environment, but crucially depends on the behavior of the human beings living in that environment.

In rural southern Africa, vulnerability to hydrometeorological threats is greatly influenced by place-based environmental, socioeconomic, political, and climatic conditions (Shiferaw et al. 2014). The most common hydrometeorological threats that affect the semiarid tropics (SAT) in this region are high rainfall variability, droughts, floods, and low soil moisture (Masunungure and Shackleton 2018). According to Makuvaro et al. (2018), droughts and prolonged dry spells in Zimbabwe's semiarid tropics have resulted in the nonperennial flow of big rivers, reduced yields, and dried-up wells. Smallholder farmers in the SAT depend on low-input rainfed agriculture and other fragile livelihoods that are sensitive to the impacts of climate threats. They also have limited infrastructure, institutional support, and adaptive capacities (Muzamhindo et al. 2015). Flood-based farming is one of the climatesensitive livelihoods. Smallholder farmers in the floodplains of the Zambezi of Zimbabwe and Zambia (Barotse), the Shire River (a tributary of the Zambezi) of Malawi, and the Okavango Delta of Botswana plant second crops after floods begin to recede (Puertas et al. 2015). Harvesting is done during August and September. However, uncertainties related to rains and floods may destroy the crops under the flood-based farming system. The lack of agricultural extension services and markets also make smallholder farmers susceptible to the impacts of climate threats (Spear et al. 2018). Where government departments are not decentralized, local proactive disaster risk reduction (DRR) programs are reduced, and reactive approaches to environmental threats keep smallholder farmers' capacities limited. In some instances, nongovernmental organizations (NGOs) and government provisions have prevented beneficiaries from pursuing other sustainable initiatives. Coupled with high poverty and limited employment opportunities, these conditions amplify smallholder farmers' vulnerability (Jiri and Mafongoya 2018). Zimbabwe has not been spared by these conditions. In 2014, it ranked 175 out of 187 countries of the world in terms of human development; $72 \%$ of its population were living below the income poverty line (UNDP 2014). In 2015, about $7 \%$ of the population were formally employed (GoZ 2015; UNDP 2016). Smallholder farmers have limited access to primary health care, water, sanitation, and hygiene (Mavhura, Manyena, and Collins 2017). Unemployment and poverty rates remain very high, forcing smallholder farmers to rely on rainfed farming (Masunungure and Shackleton 2018).

The vulnerability of the SAT in southern Africa comes on the backdrop of projections of increased water stress, declining agriculture productivity, increased food insecurity, and malnutrition (Klein et al. 2014). Floods and droughts are also projected to increase in frequency and intensity, increasing the exposure of smallholder farmers. The exposure is worsened by high levels of sensitivity of the social-ecological systems and the limited capacity of institutional actors who respond to the emerging threats (Jiri and Mafongoya 2018). Rural economic growth is slowing down, while unemployment, food insecurity, and poverty are increasing. Even the mixed crop-livestock systems, that tended to adapt to erratic rains, are becoming less viable in many places. This is because soil moisture for both fodder and rainfed crop production is depleted by long dry spells and droughts. Animal husbandry is also at risk to endemic diseases in some countries, including Zimbabwe and Namibia (Spear et al. 2018). In view of these conditions, community vulnerability studies enable an exploration of societal capacities and exposure in space and time. The combination of exposure and capacity allows the concept of vulnerability to link across problem areas and geographical levels. While changes in the environment are a source of exposure, sensitivity to these is the basis for defining the degree to which certain places are more or less vulnerable than others (Muzamhindo et al. 2015). Thus, exposure is closely linked to the social conditions of a system under study.

The literature on political economy has enhanced our understanding of vulnerability to hydrometeorological threats. The concept of vulnerability in the political economy tradition evolved in response to the purely hazardoriented disaster risk perspective during the 1970s (Collins 2008). Unlike the hazard paradigm that answers the "what," "where," and "when" questions, political economy addresses the "who," "how," and "why" of vulnerability to threats (Aboagye 2012). In this way, the drivers and effects of differential susceptibility emanating from endogenous factors of social systems are the mainstay of 
vulnerability in political economy (Wisner et al. 2004). This enables exploration of uneven resource access within a particular context (Aboagye 2012).

Where major disaster events are rare, social systems' demand for investment in disaster risk reduction (DRR) is usually limited (Kolen and Helsloot 2014). Where frequent low-magnitude hazardous events occur, some governments may be unwilling to address vulnerability issues because of the limited benefits from the increased costs (Kenny 2012; Shreve and Kelman 2014). Most vulnerability studies focus on high-impact disasters and their temporal and spatial analyses. Yet high frequency, low-impact hazards have a cumulative potential to severely disrupt or damage social and economic systems (Ndah and Odihi 2017). There is limited knowledge in the global south about the creation of vulnerability to hydrometeorological threats. Since vulnerability is dynamic, multidimensional, and scale-dependent (Hewitt 2013; Wilhelmi and Morss 2013), there is a need to frequently review the vulnerability of communities to particular threats at various levels and scales. At the local level, such analyses are greatly needed because the impacts of shocks and stresses are place-specific. This study explores the creation of vulnerability to hydrometeorological threats in the northern semiarid tropics of Zimbabwe. It seeks to answer the question in what ways communities in the northern SAT of Zimbabwe are vulnerable to hydrometeorological threats. To address this question, a systems analysis approach is used.

\section{Systems Analysis in Disaster Vulnerability}

Systems thinking is an analytical approach to a problem that views the operations and interconnections of elements in a large structure over time, to predict their behavior and devise changes to the components with a view to coming up with desired outcomes (Arnold and Wade 2015; Kapp et al. 2017). The application of systems theory in disasters, energy, education, medicine, and development programs has been on the rise in recent years (Lich et al. 2017; Mavhura 2017; Tetuan et al. 2017; Cabrera et al. 2018; Domenech et al. 2018; Molderez and Ceulemans 2018). Most studies apply systems methods to develop conceptual frameworks rather than to analyze the problem. In disaster scholarship, many studies have concentrated on the impact of a single threat such as floods (Douglas 2017) or cyclones (Chikoore et al. 2015), which may conceal the impacts of other hazards. Although drought plays a significant role in explaining crop failure in rainfed farming, for example, it is only one of the many factors that influence local farming decisions and outcomes. The impact of drought is felt in complex ways shaped by the interactions of many stressors and shocks (Coulibaly et al. 2015). Understanding the complex human-environment interactions in which farmers are living is needed for effective policy interventions. In Africa, the vulnerability of SAT communities cannot be dealt with successfully without considering broader issues including historical land imbalances, land tenure systems, poverty, and the smallholder farmers' own concerns (Masunungure and Shackleton 2018). Rather, a holistic systems approach that considers the multiple exposures to multiple threats, as well as the social and biophysical challenges, is needed (Rurinda et al. 2014). A holistic picture of the context is also needed when designing and implementing DRR policies and programs. Failure to consider the multiple contributing factors can sometimes reinforce the structural and political factors that contributed to vulnerability in the first place.

A systems theory is suitable for analyzing nonlinear, complex interactions of variables and their effects through causal mechanisms and feedback circuits (Lane et al. 2016). In such interactions, it is possible to understand why certain social systems behave in particular ways over time. The need for systems thinking is great where communities depend on natural resources (Mock et al. 2015). A systems approach has the potential to help stakeholders understand complex interactions from two vantage points: events and patterns. Stakeholders can engage in three ways of thinking: (1) system-as-cause thinking; (2) operational thinking; and (3) closed-loop thinking (Lich et al. 2017).

System-as-cause thinking scrutinizes the structure of the system (endogenous factors) as the drivers of the problem, leaving out variables that are outside the system's boundary (exogenous factors). For example, the causes of vulnerability to food insecurity in a rural village may be blamed on local soil conditions, rainfall patterns, and use of farming inputs, among other factors. Yet external factors such as global markets, irrigation, and erosion upstream might be pushing villagers out of the business of farming. This is because the village is embedded in nested dynamics that operate at different levels of spatial, ecological, and socioeconomic scales (Mock et al. 2015).

In contrast, operational thinking describes the incoming and outgoing of stocks, flows, and rates that change the system structure. For example, one can track the progression of vulnerability to flooding in a village through its root causes, dynamic pressures, and unsafe locations as stocks and flows into the flooding causation process (Khazai et al. 2014). Bola et al. (2014) suggest examining the causes of vulnerability (stock) by analyzing the flow of the six livelihood capitals (physical, social, natural, financial, human, and political).

Closed-loop thinking identifies the complex nonlinear interactions and feedbacks in the structure of a system. Such interactions usually lead to a vicious cycle where predisaster conditions are reinforced (Muhonda et al. 2014). 


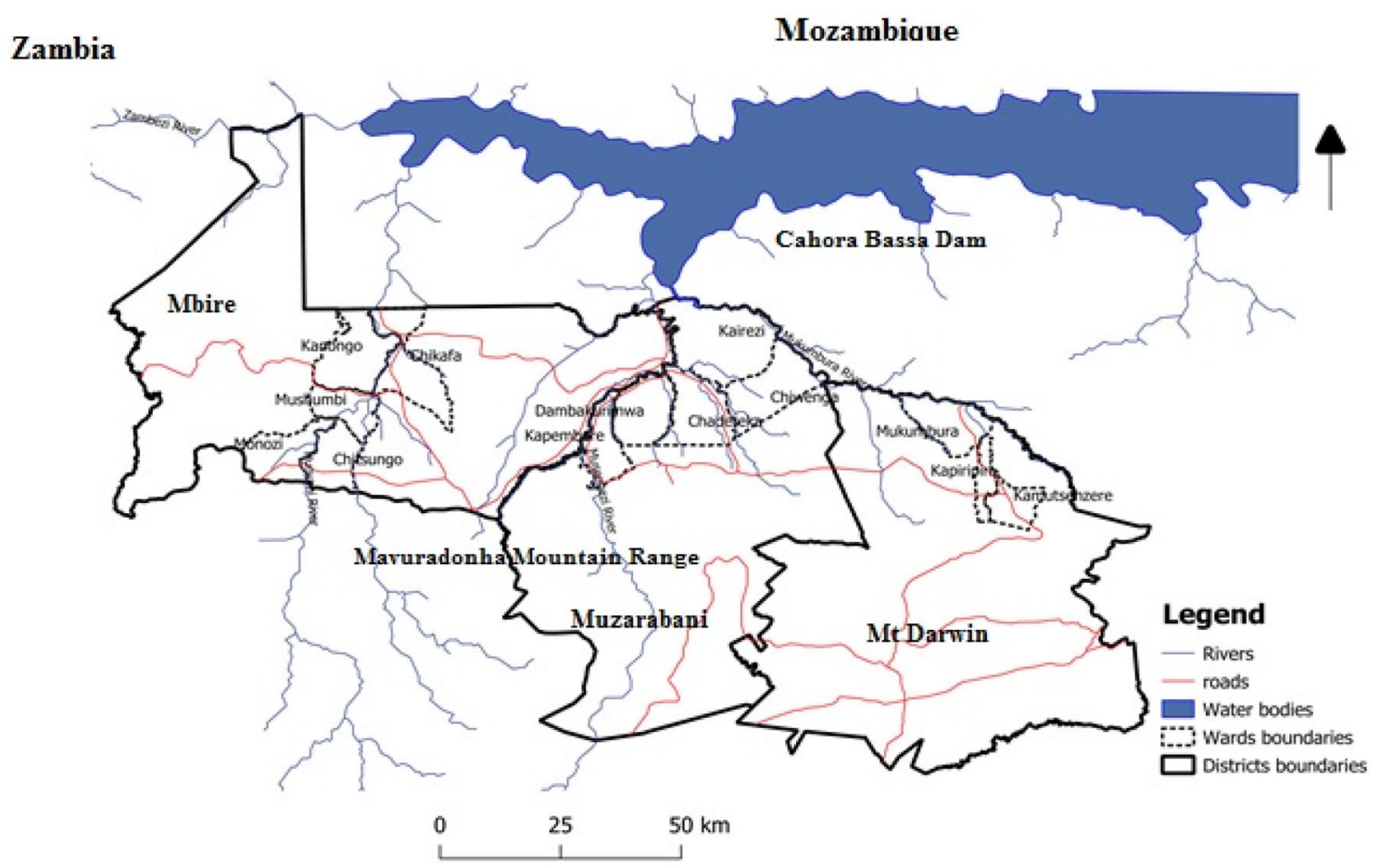

Fig. 1 The case study wards in the Mbire, Muzabarani, and Mt Darwin districts in Mashonaland Central Province of northern Zimbabwe

For example, Mavhura (2018) found that the physical and socioeconomic conditions of rural communities in Zimbabwe were mutually inclusive; each one reinforced the other(s) in causing vulnerability to flooding. Causal loop diagrams (CLD) and stock-flow diagrams (SFD) are often used to synthesize variables shaping systems structure and behavior over time. Models can be iterated and simulated to quantify diagrammed connections, describe patterns, and compare intervention measures over time (Lane et al. 2016). In this way, systems thinking becomes a robust method of learning how system elements behave and influence each other over time. Stakeholders using systems theory can explore their problem in different but complementary ways (Lich et al. 2017). They can design solutions to problems in the context of driving forces, including the limits to system change and the factors undermining or propelling positive changes.

\section{Materials and Methods}

This section begins with a description of the study area in the northern semiarid tropics of Zimbabwe. Section 3.2 explains the methods used in collecting and analyzing data. The data collection methods include interviews, focus group discussions, transect walks, and documentary analysis.

\subsection{Description of the Study Area}

The study was carried out in 2018, in 13 wards of the northern semiarid tropics situated in three districts of Zimbabwe: Mbire, Muzarabani, and Mt Darwin (Fig. 1). The wards are administrative divisions (counties) in each district where policy-making processes and development programs start. They are chaired by councilors elected by a simple majority (de Visser et al. 2010). Five of the wards were from Mbire District: Kanongo, Mushumbi, Chitsungo, Chikafa, and Monozi; five from Muzarabani: Chadereka, Dambakurima, Kapembere, Kairezi, and Chiwenga; and three from Mt Darwin: Mukumbura, Kamutsenzere, and Kapiripiri. Each ward had an average of 35 villages, while each village had about 40 households. Table 1 shows the basic demographic statistics of the 13 wards.

These 13 wards are located in the middle Zambezi Valley that extends into Mozambique on a few meters above sea level. The topography of the study area is generally a flat terrain dissected by a system of rivers that channel into the Zambezi River in Mozambique. The Zambezi River eventually discharge its water in the Indian Ocean. All the five wards from Mbire District are located along Hunyani River that flows in northeasterly direction. About 15 villages in Mushumbi Ward are located in-between Dande and Hunyani Rivers. In Muzarabani District, 
Table 1 Basic demographic statistics of case study wards in Mbire, Muzabarani, and Mt Darwin districts in Mashonaland Central Province of northern Zimbabwe. Source ZimStat (2012), UNDP (2016)

\begin{tabular}{|c|c|c|c|c|c|c|c|c|c|}
\hline District & Ward & $\begin{array}{l}\text { Male } \\
\text { population }\end{array}$ & $\begin{array}{l}\text { Female } \\
\text { population }\end{array}$ & $\begin{array}{l}\text { Total } \\
\text { population }\end{array}$ & $\begin{array}{l}\text { No. of } \\
\text { households }\end{array}$ & $\begin{array}{l}\text { Literacy } \\
\text { rate }\end{array}$ & $\begin{array}{l}\% \\
\text { below } \\
\text { poverty } \\
\text { line }\end{array}$ & $\begin{array}{l}\% \text { Population without } \\
\text { proper water, } \\
\text { sanitation, and } \\
\text { hygiene }\end{array}$ & $\begin{array}{l}\% \\
\text { Households } \\
\text { in } \\
\text { traditional } \\
\text { huts }\end{array}$ \\
\hline \multirow[t]{5}{*}{ Mbire } & Kanongo & 3073 & 3033 & 6106 & 1337 & 86.3 & 88.2 & 75 & 75 \\
\hline & Mushumbi & 2457 & 2437 & 4894 & 1126 & 86.2 & 88.4 & 69 & 58 \\
\hline & Chitsungo & 3414 & 3503 & 6917 & 1489 & 87.1 & 88.6 & 68 & 69 \\
\hline & Chikafa & 3292 & 3493 & 6785 & 1509 & 85.6 & 89.4 & 75 & 75 \\
\hline & Monozi & 1493 & 1503 & 2996 & 624 & 86.4 & 89.3 & 74 & 75 \\
\hline \multirow[t]{5}{*}{ Muzarabani } & Chadereka & 3699 & 3806 & 7505 & 1594 & 87.1 & 88.2 & 68 & 56 \\
\hline & Dambakurima & 2516 & 2623 & 5136 & 1118 & 87.2 & 87.6 & 67 & 61 \\
\hline & Kapembere & 2411 & 2597 & 5008 & 1125 & 87.1 & 88.6 & 68 & 60 \\
\hline & Kairezi & 4853 & 4487 & 9340 & 1953 & 85.1 & 89.1 & 71 & 79 \\
\hline & Chiwenga & 2964 & 2974 & 5938 & 1232 & 84.6 & 89.4 & 72 & 81 \\
\hline \multirow[t]{3}{*}{ Mt Darwin } & Mukumbura & 5882 & 6347 & 12229 & 2960 & 87.9 & 79.7 & 63 & 71 \\
\hline & Kapiripiri & 2039 & 2243 & 4282 & 1030 & 87.4 & 80.1 & 62 & 73 \\
\hline & Kamutsenzere & 2607 & 2905 & 5512 & 1409 & 87.5 & 79.4 & 62 & 72 \\
\hline
\end{tabular}

the Chadereka, Dambakurima, Kapembere, and Kairezi wards are on the eastern banks of Musengezi River that discharges into Zambezi River near Cahora Bassa Dam. These wards are also dissected by Nzou-Mvunda, Hoya, Musingwa, Mukumbura, and Kairezi Rivers. The Chiwenga Ward boarders Zimbabwe and Mozambique along Chiwenga and Mukumbura Rivers. In Mt Darwin District, tributaries of Mukumbura River affect Mukumbura, Kapiripiri, and Kamutsenzere wards. These rivers increase community exposure to riverine floods. Throwbacks (also known as backflow flooding) that happen after intense precipitation are the most common type of floods in all the 13 wards. Backflow floods occur when tributaries fail to empty into major rivers. As a result, water piles up at river confluences and flows backwards, inundating the nearby areas.

Cyclones developing in the Indian Ocean also penetrate easily into the valley and cause extensive floods while creating silt and residual moisture that enhance flood-based farming. Flood disasters manifest themselves through inundation of villages, livelihood destruction, outbreaks of waterborne diseases, and damages to critical infrastructure. For example, 2000 Cyclone Elin caused great damage to roads, bridges, clinics, and schools in the valley (DCP 2015). In 2007, the government reported that about 200 families (approximately 1200 people) were displaced by floods and 400 huts were destroyed in Chadereka (DCP 2007). The Herald newspaper of Zimbabwe reported on road damages in Mbire wards as a footprint of the perennial flooding in the district (Guvamombe 2011). Flash floods are also a common feature in the area. The Mavuradonha
Mountain Range is the source of the flash floods and strong winds in the valley. This mountain separates the middle Zambezi Valley from the highveld areas of Zimbabwe. The worst floods were recorded in 2000, 2008, 2011, 2015, and 2017 (CRED 2018). These flood events resulted in significant social distress and suffering among many smallholder farmers (Mavhura, Manyena, and Collins 2017). Although the system of rivers increases vulnerability to floods in the 13 wards, it provides fertile alluvium and residual moisture along riverbanks and floodplains.

Mopane (Colophospermum mopane) and acacia (thorn trees) forests and woodlands dominate the vegetation in the 13 wards under study (Mavhura 2017). The two vegetation types are associated with sodic and alluvial soils. They offer a natural buffer against riverine floods and protect soils from erosion. The mopane woodland is also a source of browse for both domestic animals and wildlife and provides timber, fuelwood, and construction materials for gardens, cattle pens, and traditional huts. Destruction of these forests and woodlands can increase community vulnerability to floods.

The 13 wards are in agroecological regions 4 and 5 where potential evaporation exceeds precipitation. Annual rainfall ranges from 350 to $650 \mathrm{~mm}$, whereas temperatures can be as high as $400{ }^{\circ} \mathrm{C}$ (Muhonda et al. 2014). The rainfall season (December to March) is characterized by drought, frequent and intense mid-season dry spells (Jiri and Mafongoya 2018). The major economic activity in these wards is smallholder farming, accounting for more than $97 \%$ of employment (ZimStat 2012). The smallholder farmers have limited access to natural land. Their plots are 
usually very small (less than 1.5 ha), and held under a traditional tenure system that does not provide title deeds to the land. Village heads allocate such pieces of land to their respective households while the community shares grazing pastures. These features make smallholder famers extremely vulnerable to climate-related threats. Major crops grown include maize, small grains, cotton, and edible dry beans. Small-scale livestock production (cattle, goats, and sheep) is also practiced (Bola et al. 2014). Both crop and livestock production are constrained by floods, droughts, and hail and wind storms (Mavhura 2017). Floods and droughts remain the most frequent and costly hazards in the northern SAT of Zimbabwe, making the region a prime area of hydrometeorological threats. Other significant losses from hydrometeorological threats may be caused by the cumulative effects of high-frequency, low-magnitude hazards that affect the economically challenged members of society. It is against this background that this study explored the ways in which communities in the northern SAT of Zimbabwe are vulnerable to hydrometeorological threats.

\subsection{Methods}

Thirteen wards were selected by their respective Rural District Councils (RDC) from a stratified sample based on their drought and flooding profiles. Five of the wards were from Mbire: Chikafa, Mushumbi, Chitsungo, Monozi, and Kanongo; five from Muzarabani: Kairezi, Chiwenga, Dambakurima, Kapembere, and Chadereka; and three from Mt Darwin: Mukumbura, Kamutsenzere, and Kapiripiri. The 13 wards were deemed to be the most drought- and flood-affected communities in the districts. The study was predominantly qualitative in nature and purposively selected smallholder farmers with in-depth knowledge about vulnerability to hydrometeorological threats. Interviews, focus group discussions (FGD), transect walks, and a review of past disaster events in the study area were used to gather data. The four data sources were triangulated to further corroborate, validate, and improve the reliability of the findings.

\subsubsection{Interviews}

Interviews formed one of the principal means of collecting primary data because they provided detailed information about smallholder farmers' vulnerability experiences and the meaning of those experiences (Castillo-Montoya 2016). Sixteen interviews were conducted with one councilor from each ward and three civil protection staff from each district during the first half of 2018 until the data reached a theoretical saturation level (Saunders et al. 2018). Seven of these key informants were females and nine were males.
Their ages ranged from 30 to 55 years. The ward councilors were selected on the basis of their development and civil protection role in their respective communities. They are the gatekeepers who coordinate government and ward development programs. The councilors also chair the civil protection committees in their wards and link with other civil protection structures at the district, provincial, and national levels. NGOs also liaise with councilors in implementing their programs. Each interview lasted for about $45 \mathrm{~min}$. The interviews were conducted mainly in English because all the key informants could understand and communicate in this language. The interviews focused on four themes: hydrometeorological threats and their frequencies, livelihood and population exposure, capacities, and the vulnerability conditions of smallholder farmers. There were three advantages associated with the interviews. First, the personal contact during the interviews resulted in a high rate of return. Second, using open-ended questions evoked responses that were meaningful, culturally salient to the key informant, detailed, and explanatory in nature (Roberts et al. 2014). Finally, probing and followup questions during the interviews gave the participants the opportunity to respond in their own words.

\subsubsection{Focus Group Discussions}

One focus group discussion was conducted in each of the 13 wards during the second quarter of 2018. One hundred and fifty-five smallholder farmers participated in the FGD, an average of 12 people per group. This was a manageable number because a large group could have turned unwieldy and hard to manage, denying a voice to inarticulate members when disagreements arose. The participants were males (74) and females (81), between the ages of 20 and 60 , who were capable of explaining their experiences with climate threats, exposure, capacities, and vulnerability conditions from an insider point of view. The participants drew sketch maps, causal loop diagrams, and stock-flow diagrams to show the interconnectedness of the vulnerability variables. These diagrams then formed the basis of the stock-flow diagrams that were later drawn using Vensim PLE 7.2 software. ${ }^{1}$ The FGD participants were randomly chosen from different villages in each ward by their village heads. This method yielded a rich collective view that could not be obtained from straightforward interviews. It also produced more filtered, socially controlled, and more neutral findings (Silverman 2013). The focus group sessions were conducted in the usual meeting places of each community that afforded a maximum degree of accessibility to participants (Cohen et al. 2011). Each focus group session lasted for about $2 \mathrm{~h}$ because the participants

\footnotetext{
${ }^{1}$ https://vensim.com/free-download/.
} 
needed ample time to draw sketch maps and other diagrams that showed the interconnectedness of the vulnerability variables. The sessions were held in the local language, Shona for ethical reasons. A translator was sought to facilitate communication during the FGD.

\subsubsection{Transect Walks}

Semistructured walk-through analyses were conducted in the 13 wards in June and July 2018. FGD participants led the field observations soon after each discussion. In this way, there was a balance in observing places of interest raised during the discussions. Some of the variables observed include settlements along riverbanks, floodplain plots, woodlots, and livestock, among others. Engaging in semistructured observations in natural settings allowed the gathering of data that illuminated and explained the communities' vulnerability in a less predetermined manner.

\subsubsection{Review of Background Material}

The study started with a review of basic data on country profiles and maps on disaster and hazard profiles that are provided by the Prevention website (Ndhlovu 2018) and the EM-DAT: The Emergency Events Database (CRED 2018). Specific loss data for the study area were gathered from the Zimbabwe Civil Protection website (DCP 2013) where official reports and other documents were reviewed. Newspaper articles from the local press were also reviewed. These data supplemented the information obtained from the interviews, FGD, and transect walks.

\subsubsection{Data Analysis}

The interview and FGD data were subjected to thematic analyses, which enabled making sense of the shared subjective meanings and experiences (Braun and Clarke 2012) of the smallholder farmers when faced with hydrometeorological threats. The coding process became the most crucial phase of the data analysis and formed the basis of the emerging findings. This involved open coding, where each statement was analyzed and notes made to reflect the situation and meanings implied by the key informant (Vaismoradi et al. 2016). The field notes became the principal memos that were integrated in the SFD. The analytical process provided an in-depth understanding of the creation of vulnerability to hydrometeorological threats. Vensim PLE 7.2 software was used to draw stockflow diagrams based on the sketches from the focus group discussions depicting the drivers of vulnerability and the interactions of the underlying variables. To validate the SFD, expert opinion was sought among local academics and DRR practitioners. The experts looked for clarity, causality existence, cause insufficiency, additional cause, cause-effect reversal, and predicted effect existence (Alasad et al. 2013). However, the experts validated the SFD basing on their personal beliefs about the direction of the causal links (Burns and Musa 2001).

In systems diagramming, the distinction between stocks, variables, flows, and connectors was very important in analyzing the data. Stocks were elements that tended to accumulate or decrease in quantity within the models. In order to draw the SFD, Vensim PLE 7.2 software employed rectangles and squares to represent stocks (levels). Variables became other identified elements that influenced the structure of the models. The variables were drawn outside boxes in order to distinguish them from stocks. Flows (rates) were activities that tended to fill or drain stocks. Piped arrows feeding into or draining out of stocks represented the flows. Connectors were arrows that linked various elements of the models including stocks, flows, and other variables, to indicate relationships and influence.

\section{Results}

Ward communities in the northern SAT of Zimbabwe are vulnerable to hydrometeorological threats including droughts, floods, lightning, and storms. All the key informants $(n=16)$ and focus groups concurred that droughts and floods are the most common hazards in the region. Most of the key informants (15 out of 16) reported that floods mostly affect settlements and fields along riverbanks, while windstorms damage huts in open areas and places close to mountains. While droughts and floods occur on an annual basis covering wide areas, lightning and storms are usually localized, small-scale events but with high frequency. Focus groups revealed that high magnitude floodwaters could rise to levels above $2 \mathrm{~m}$ in low-lying areas. During such events, rivers including Hoya, Musengezi, Dande, and Hunyani burst out, putting villagers settled either along the riverbanks or at river confluences at high risk. The Mushumbi, Kanongo and Chikafa focus groups cited the 2015 floods as high magnitude floods in which Hunyani River swept away most settlements and crops within a distance of up to $1 \mathrm{~km}$ from its riverbanks. During that year, backflow floods occurred at the confluence of Dande and Hunyani Rivers in Mushumbi. Bwazi River also back-flowed when its waters piled up at its confluence with Hunyani River in Chikafa. In Chistungo community, floods inundated Makwatsine Secondary School including teachers' cottages.

Low magnitude floods happen every year with floodwaters below $2 \mathrm{~m}$. Focus groups revealed 10 variables creating and exacerbating their vulnerability to hydrometeorological threats. The variables include flood recession 




Fig. 2 Interaction of variables underlying vulnerability to hydrometeorological threats in the northern semiarid tropics (SAT), Zimbabwe (Rreinforcing; B-balancing)

farming, colonial land imbalances, shortage of arable land, land fragmentation, overstocking, overgrazing, reliance on rainfed farming, high unemployment, little savings, and low income. The communities also experience small-scale flash floods that usually create mudslides. Such floods are common in Chistungo, Monozi, and Kamutsenzere due to their proximity to Mavuradonha Mountain Range where heavy rains turn dry streams and gullies into rushing currents that may burry crops and traditional huts. The Mavuradonha Mountain Range also creates corridors through which strong winds blow and destroy traditional huts. The Monozi focus group indicated that "storms uproot trees and damage our huts." All the key informants agreed that the high frequency of localized windstorms is detrimental to poor-resourced households, which makes these storms significant hazardous events.

Rainfed and flood-based farming constitute the major economic activity among the smallholder farmers in the 13 wards. The two farming systems are marked by low productivity levels. On the one hand, droughts and long dry spells severely affect rainfed farming. On the other hand, floods destroy crops under flood-based farming system. Consequently, smallholder farmers realize low income and have increased poverty levels. Low incomes among the smallholder farmers generate ripple effects on their socioeconomic lives. About $70 \%$ of smallholder farmers stay in traditional huts made of poor building materials (wooden poles and grass). The farmers cannot afford insurance for their homes and crops, buy farming inputs (fertilizers, herbicides and pesticides), and mechanize their farming systems. Low income also reduces the health seeking behavior of the smallholder farmers. About $69 \%$ of the smallholder farmers do not have access to proper water, sanitation, and hygiene (WASH) facilities. This increases their vulnerability to hydrometeorological threats.

There was a consensus among the key informants and the focus group participants that the major drivers of community vulnerability are rooted in the skewed distribution of land, from which the smallholder farmers derive their livelihoods (Fig. 2). The participants shared stories of how the unequal access to arable land promulgated by the colonial land tenure systems more than four decades ago was driving their vulnerability. "The colonial land imbalance fuels land shortage coupled with high population densities. This results in land fragmentation into uneconomic units, overstocking and overgrazing," reported the Chitsungo focus group. The group explained how land fragmentation, overstocking, and overgrazing affect each other. As shown in Fig. 2, a positive reinforcing loop $\left(R_{1}\right)$ emerged when increasing land holding fragmentation further increased overgrazing within the community (positive cascading effect), while a balancing loop $\left(\mathrm{B}_{1}\right)$ emerged when increased overgrazing reduced overstocking. The Chitsungo focus group explained that land fragmentation 


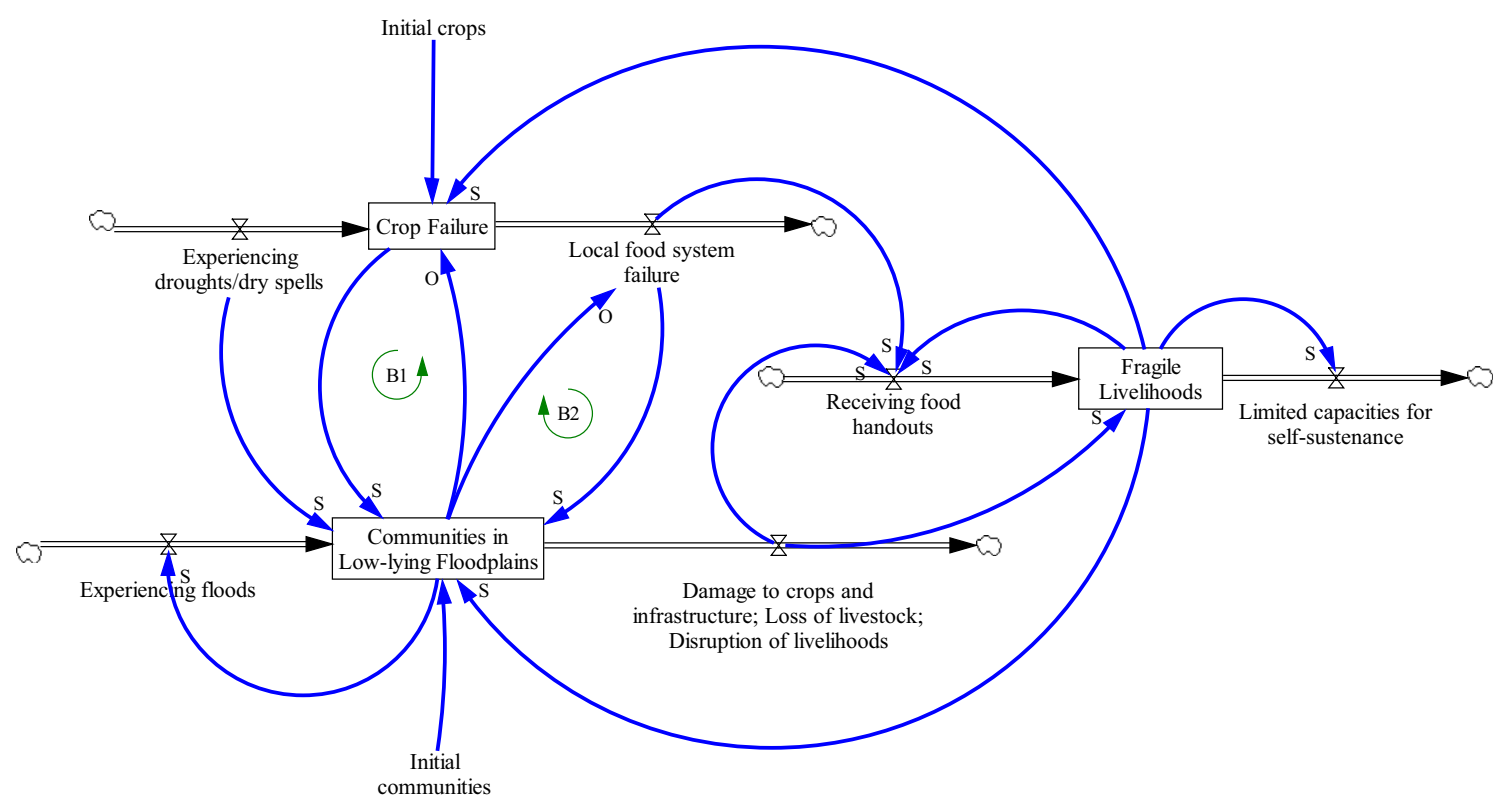

Fig. 3 Construction of vulnerability to floods and droughts in the northern semiarid tropics (SAT), Zimbabwe (B-balancing). Note The letters "S" and "O" at the arrowheads mean "support" and "oppose," respectively

reduced grazing pastures, resulting in overgrazing. Other positive reinforcing loops identified and discussed by focus groups include those between overgrazing and shortage of land $\left(\mathrm{R}_{2}\right)$; overstocking and shortage of land $\left(\mathrm{R}_{3}\right)$; shortage of land and smallholder farming system $\left(\mathrm{R}_{4}\right)$; hydrometeorological threats and rainfed farming system $\left(\mathrm{R}_{5}\right)$; and floodplain and rainfed farming systems $\left(\mathrm{R}_{6}\right)$. Both reinforcing and balancing effects emerged from the structure of the feedback loops as forms of systems behavior among the northern SAT communities. However, 10 of the $16 \mathrm{key}$ informants admitted that the interactions of these variables do not always result in disasters. There are isolated cases of storms and lightning that remain hazardous events. Only those that exceed the capacity of poor smallholder famers turn into significant disasters.

Interviewees also pointed out how the rainfed and floodbased farming systems can create double vulnerability. Rainfed farming is practiced both within and outside of riverbanks, in low-lying depressions, and on uplands. Flood-based crop production is practiced along major rivers: the Hunyani, Musengezi, and Hoya. The smallholder farmers have constructed their settlements along rivers as they search for water for domestic uses. Other smallholder farmers plough inside riverbeds, in interfluves, and on small islands in rivers. The flood-based farming system depends on the recession of floodwaters that leave moisture for crop production during the post-inundation period. "Floods bring a lot of sediment load that creates rich alluvial soils for our crops," emphasized a male informant from Mushumbi ward.

Although rainfed farming remains the mainstay of the SAT economies, all focus groups admitted that it is economically unviable, partly due to seasonal droughts, dry spells, and floods (Fig. 3). They argued that the little amount of annual rainfall received (about $400 \mathrm{~mm}$ ), the wide variation in the onset and cessation of rainfall dates, and the occurrence of the mid-season dry spells during critical periods of crop growth combined to cause total crop failure in most years. "Over the past decades, we have been experiencing erratic rain seasons characterized by unpredictable lengths, high temperatures, and variable rainfall amounts," reported the Mukumbura focus group. Consequently, the smallholder farmers have limited options to satisfy their food requirements in terms of quantity and quality. This results in severe food insecurity and malnutrition. Striking a balance between short-term food requirements and long-term food production is a big challenge for the villagers. Some focus groups complained that the perennial food shortage was resulting in high dependence on food handouts from NGOs or the government that inevitably undermined their efforts to build capacities for sustainable livelihoods and food selfsustenance.

All the focus groups also admitted that some smallholder farmers were exposed to seasonal floods often triggered by intense precipitation, cyclones, and backflow 


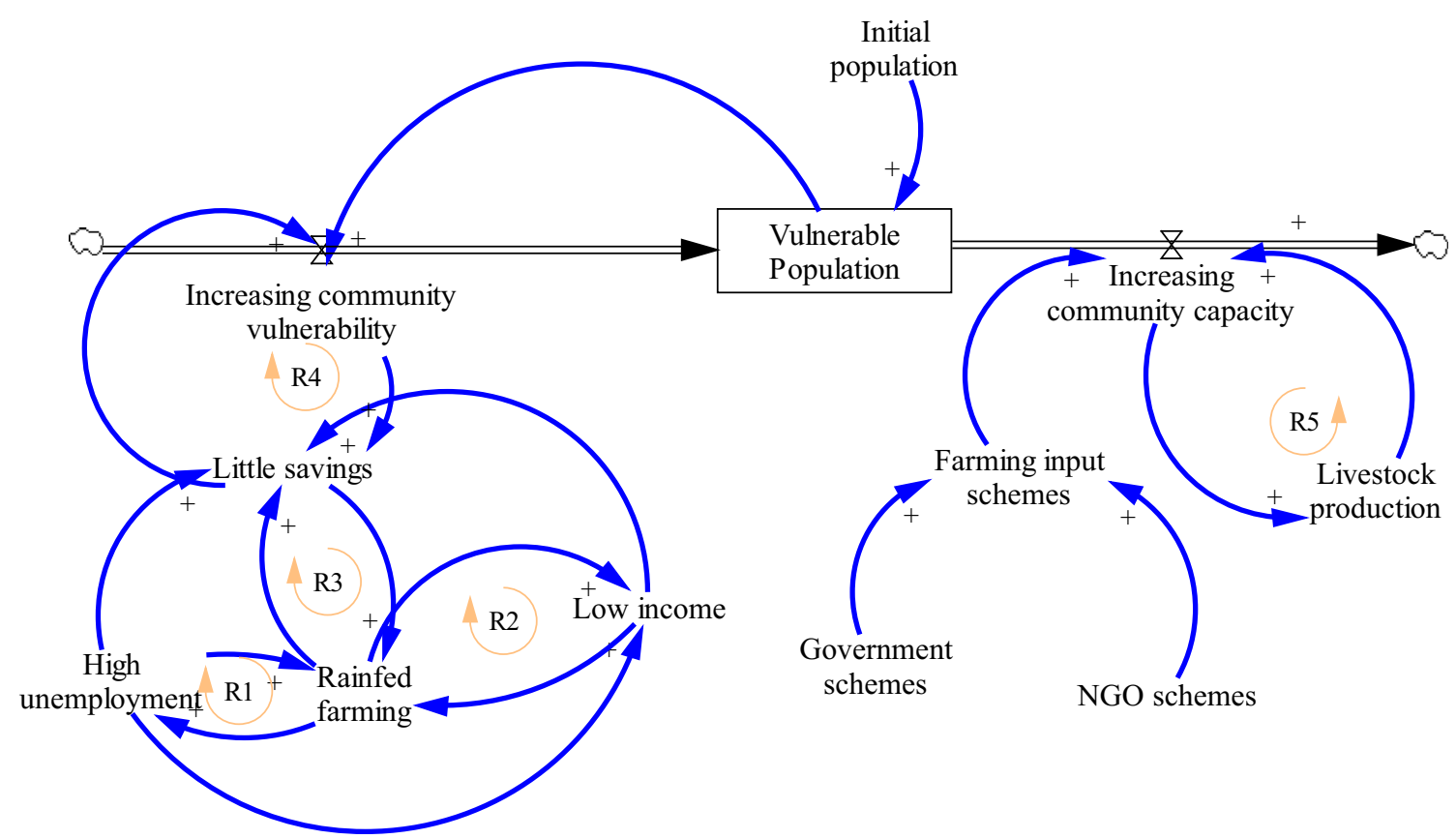

Fig. 4 Key drivers of social vulnerability to hydrometeorological threats in the northern semiarid tropics (SAT), Zimbabwe (R—reinforcing)

of water along the river networks. Backflow flooding was reported along Musengezi, Hunyani, Mukumbura, and Hoya Rivers. The smallholder farmers settled in low-lying areas of Sangu Village in Mushumbi were the most affected during the 2015 floods. Most of the key informants (11 out of 16) indicated that floods in the Sangu Village rose to about $5 \mathrm{~m}$, drowning goats and sheep. In Chadereka ward, social amenities, including clinics, schools, and markets, were damaged by floodwaters during the same year. "Even small-scale floods destroy our crops along floodplains, damage our houses, roads, and seriously disrupt other livelihoods," reported the Chadereka focus group. Floods that were accompanied by lightning and storms also damaged roofs of classrooms and houses in Kamutsenzere in 2017. This makes floods the most frequent and costly threat in terms of hardships and economic loss in the northern SAT communities.

Although floods and droughts are two extremes on the hydrometeorological continuum, focus groups used diagrams to explain how they influence each other in increasing community vulnerability (Fig. 3). The fear of crop failure from droughts and dry spells promotes floodbased crop production. This creates the undesirable side effect of community exposure to floods and livelihood disruption during the rainy seasons. Yet the flood-based farming system itself improves food security, especially through the cultivation of maize, the staple food. This creates a balancing loop $\left(\mathrm{B}_{1}\right)$. Another balancing effect is created between local food system failure and the occupation of low-lying floodplains $\left(\mathrm{B}_{2}\right)$. Consequently, the smallholder farmers' livelihoods remain fragile, with limited capacities for self-sustenance. A vicious circle of vulnerability is created when fragile livelihoods promote food insecurity and loss of livestock from droughts and floods. Smallholder farmers then face two additional challenges. First, the flood recession farming system is increasingly competing with the rainfed farming system. Yet there is limited land along the floodplain, causing social disputes among the community members. Not every household has access to arable land along the floodplain. The village heads exercise their prerogative to decide whom to allocate a piece of land along the floodplain. Some focus groups reported stories of village heads who were allocating big farming plots along the floodplain to their close relatives and friends only. The focus groups argued that access to flood-based farming land depended on one's relations with the village head, not on a household's need. In the absence of land-use zoning, the smallholder farmers convert woodlands into arable land and crop cultivation extends into marginal floodplains. Although this temporarily improves livelihoods and food security, two undesirable outcomes are the destruction of a natural flood buffering effect and the removal of forests that act as a windbreak against strong storms. Second, flood-based farming degrades the environment resulting in the siltation of rivers. Consequently, the smallholder farmers expose 
themselves to increased river flooding. These processes are self-supporting, increasing land degradation, poverty, food insecurity, and vulnerability.

The participants of this study all agreed that high unemployment, low incomes, and few savings chiefly drive the social dimension of vulnerability. They explained that the three variables reinforce each other, thereby creating reinforcing loops $\mathrm{R}_{1}, \mathrm{R}_{2}, \mathrm{R}_{3}$, and $\mathrm{R}_{4}$ (Fig. 4). Due to low income levels, for example, the majority of smallholder farmers heavily depend on rainfed farming that generates little income to diversify the farming sector $\left(\mathrm{R}_{2}\right)$. High unemployment also results in low disposable income and little savings at the household level. Low incomes lead to poor self-protection, as well as limited options for flood/drought mitigation, recovery, and preparedness. In this way low income is both a cause and a result of vulnerability to climate shocks and stresses. This is exacerbated by lack of social insurance and the breakdown of the rural economy. When asked if they were receiving cash transfers from relatives abroad or in urban areas, the majority of the focus group participants explained that very few households had relatives remitting cash back home. Other focus group participants pointed out that the urban folks were the ones seeking support from the rural areas due to macroeconomic problems. They narrated stories of informally employed people who depend on selling fruits and vegetables in towns and cannot afford to remit any income back home. "As a result, the communities need aid after every disaster," reported the Dambakurima focus group. In an effort to enhance farmers' capacities, NGOs and the government provide farming inputs to smallholder farmers. One key informant reported: "NGOs provide us with farming inputs. The government at times also gives us inputs through command agricultural schemes." However, the inputs are channeled into a rainfed farming system that is already under attack from both floods and droughts, thereby leading to limited income for investment into farming and other economic activities.

Despite their increased vulnerability, 13 out of 16 key informants explained that their capacity was partly enhanced by livestock production, especially cattle and goats $\left(\mathrm{R}_{5}\right.$ in Fig. 4$)$. They argued that livestock thrive in this ecological farming region. During food insecure seasons, livestock provide meat and milk products. Livestock could also be converted into cash for other household requirements. Cattle also provides draught power for the farming sector, and both goats and cattle can be exchanged for food, farming inputs, and so on. Livestock production provides a form of insurance against seasonal crop failure.

Key informants identified several factors that undermine livestock's potential contribution to the rural economy, chief among them being their mortality rates. "Livestock mortality is commonly caused by feed shortages during drought years, lack of drinking water, and the prevalence of animal diseases," argued a male informant with a large herd of cattle. Animal diseases also reduce beef and dairy production, draught power, and the overall profitability of the livestock sector. Key informants identified four main reasons why little income is realized from the sale of livestock. First, food prices increase during drought and flood events. The increased food prices weigh heavily on household incomes, pushing some households deep into hunger and malnutrition. Second, livestock production is being squeezed out of the SAT farming system due to lack of supplementary feed resources. Third, because livestock production is dependent on natural grazing, destocking is often practiced in the face of drought. Finally, the continued encroachment of crop production into grazing land poses another threat to livestock production.

\section{Discussion}

This study explored the ways in which communities in the northern SAT of Zimbabwe are vulnerable to hydrometeorological threats. What emerged is that communities are vulnerable to multiple threats due to multiple interacting factors. The unique characteristics of droughts and floods in the study may suggest that the vulnerabilities to these threats could be distinct from each other, as well as from other climate-related threats. Vulnerability has been shown to be multidimensional, differential, scale-dependent, and dynamic (Usamah et al. 2014; Mavhura, Collins, and Bongo 2017). Therefore, vulnerability studies can focus on the context of specific threats rather than on a typology of hazards.

The manifestation of community vulnerability can be distinguished by its context, including topography, climate, political processes, and socioeconomic conditions. When viewed from the social-ecological system perspective, these variables describe the human and environmental nexus that expose rural communities, erode their capacities, and increase their susceptibility to disasters. The climate and topography of an area define the region's geographical vulnerability (Usamah et al. 2014). This may vary with the exposure of smallholder farmers across the physical space of the area. Community exposure to floods increases geographical vulnerability when natural buffers are removed for either economic development or farming (Mukherjee and Takara 2018).

One way to reduce vulnerability to hydrometeorological threats is to reduce human exposure. The disaster literature is full of case studies from which lessons can be drawn to reduce community exposure. Land-use zoning and relocation are some of the lessons. In Kenya, for example, smallholder farmers' vulnerability declined when they 
embraced zoning of their land into arable land, grazing pastures, and forest/woodlands (Zaehringer et al. 2018). In the Okavango Delta, the government of Botswana permanently relocated hundreds of villagers to nearby dryland areas, following floods of three consecutive years (2009-2011) (Shinn et al. 2014). The Tokwe-Mukorsi community, Zimbabwe was also relocated in 2014 following floods related to dam failure (Mavhura, Collins, and Bongo 2017). Dube et al. (2018) recommend the establishment of human settlements away from flood-prone areas as a way of reducing human exposure.

Climate is another distinguishing factor of community vulnerability in the northern SAT. Dalu et al. (2018) suggest that extremes in climate events such as floods and droughts in southern Africa have been increasing in frequency and intensity since the 1990s. The long dry spells and droughts force smallholder farmers to settle in unsafe floodplains. However, floods destroy their livelihoods and leave the smallholder farmers in a cycle of poverty (Jiri and Mafongoya 2018). Droughts can render land marginal for farming. It can also increase vulnerability by contributing to malnutrition and famine (Shiferaw et al. 2014). To mitigate droughts and dry spells, Belle et al. (2017) suggest developing irrigation schemes. In the northern SAT, such schemes could draw water from underground sources and the network of rivers coming from areas of high rainfall. Several scholars recommend the use of drought resistant crop varieties as a mitigation measure (Bryan et al. 2013; Chikodzi et al. 2013; Mashizha et al. 2017), while Masunungure and Shackleton (2018) suggest the adoption of climate-smart approaches such as agroforestry in areas with unpredictable rains. Agroforestry can facilitate water infiltration and diminish the impacts of droughts.

Political processes may increase rural community vulnerability by depriving the populace of their livelihoods. In southern Africa, land forms the natural capital from which resources flow and services are derived (Masunungure and Shackleton 2018). Land has a knock-on impact on other forms of capitals. Changes in land use and management can increase or reduce community vulnerability to hydrometeorological threats. The current communal land tenure system (without title deeds) in northern SAT wards creates critical land shortages that force occupancy of unsafe flood basins. In Namibia and Botswana, communal land tenure increased pressure on land and caused low productivity in arid areas (Spear et al. 2018).

Social vulnerability helps to explain why individual households or societies with similar levels of exposure may be impacted differently by hazards of similar intensities (Siagian et al. 2014). This study confirms Mavhura, Manyena, and Collins' (2017) findings that low incomes, unemployment, high poverty and little savings increase vulnerability to hydrometeorological threats. Employment may create disposable income, better savings, and enhanced capacity to purchase farming inputs. This may lead to increased asset ownership, diversified livelihoods, and improved coping capacity of households (Wei et al. 2017). Low income coincides with high indices of poverty, unemployment, poor savings, and marginalization (Rufat et al. 2015). The poverty situation encourages the construction of settlements in unsafe places and the use of substandard dwellings that are destroyed by floods. Therefore, poverty needs to be addressed so as to enhance smallholder farmers' capacities. Shiferaw et al. (2014) suggest the diversification of farmers' cropping practices using a mix of crop varieties both in space and time as a way to reduce poverty. Hanjra et al. (2009a, b) argue for investment in irrigation and other forms of rural infrastructure as effective strategies of reducing poverty in subSaharan Africa. Their studies highlight several pathways and investment options through which irrigation investment could reduce poverty by promoting higher productivity, employment creation, increased incomes, and other multiplier effects on off-farm activities. However, investments in irrigation alone may not significantly reduce poverty. Rather, a package of properly sequenced interventions that are supported by good governance, community participation, and a sound macroeconomic environment is needed.

The application of systems thinking in this study revealed two farming systems that are increasing community vulnerability in the study area: rainfed and flood recession agriculture. Flood-based farming is not unique to the northern SAT of Zimbabwe. It is also practiced in Namibia as matapa farming (Mabuku et al. 2018) and in Nyaminyami District, Zimbabwe as mabonzyi farming (Tombindo and Chirau 2017). Rainfed agriculture is closely linked to the skewed distribution of land that amplifies the vulnerability conditions of smallholder farmers in Botswana, Namibia, and South Africa (Spear et al. 2018). The dependency on rainfed farming has reduced smallholder famers' capacity for vulnerability reduction. In order to improve the capacities of communities dealing with climate shocks and stressors, Liu and Lan (2015) argue for the diversification of rural livelihoods to include off-farm and non-farm activities. Unfortunately, over the decades Zimbabwe has not improved its farming beyond the rainfed system. The need to diversify the farming sector is also great considering the climate change projections of increasing water scarcity and declining crop productivity (Rurinda et al. 2015). The capacities of the smallholder farmers could also be improved by maximizing food production during favorable seasons so as to create a fallback for use during drought periods. Improved post-harvest processing and storage techniques are needed to store the produce from good years for periods extending into 
drought years. However, no single variable can explain the vulnerability of smallholder farmers. Instead, multiple interacting factors create vulnerability to climate threats. Mock et al. (2015) argue for the use of a social-ecological systems perspective in order to explore the vulnerabilities of communities that rely on the extraction of natural resources.

\section{Conclusion}

Vulnerability to hydrometeorological threats is context specific, multi-dimensional, and differential. Multiple contextual factors interact in non-linear ways to create different dimensions of vulnerability. Each of the dimensions of vulnerability has a set of variables that define the nature and extent of vulnerability to identified threats. It is therefore prudent for vulnerability studies to focus on how contextual variables interact to create vulnerability to specific threats. In order to reduce the vulnerability of smallholder farmers, this study recommends five policy options for government and NGO consideration. First, human exposure to floods can be reduced through land-use zoning into unsafe, arable, and grazing land. All low-lying areas along riverbanks, interfluves, and close to confluence of rivers are unsafe places for either human settlement or farming activities. Arable farming land should be set outside the unsafe zones. The actual distance from river banks is context-based. Second, the government may consider resettling smallholder farmers from the unsafe floodplains. The resettlement exercise can be undertaken within the broader framework of land reform program that the government of Zimbabwe is implementing. Third, smallholder farmers should be assisted to move away from rainfed to irrigation farming in order to mitigate droughts and dry spells. The irrigation schemes can draw water from aquifers in Mavuradonha Mountain Range, and the perennial rivers in the valley. Fourth, the devastating impacts of droughts and dry spells could be mitigated by adopting drought tolerant varieties and short-seasoned crops. Drought tolerant cultivars such as pearl millet, sorghum, and rapoko can withstand low soil moisture and high temperatures experienced in the northern SAT region of Zimbabwe. Alternatively, smallholder farmers can grow short-season crop varieties that can be harvested within two and half months. Lastly, the smallholder farmers' capacities could be improved through diversifying their livelihoods. Diversification of rural livelihoods will mean moving away from dependency on farming, which is not economically viable in the study area. The smallholder farmers can diversify their cropping systems, practice rotational grazing and agroforestry, or engage in petty business as a way to accumulate wealth. Grazing practices including setting aside or postponing grazing while forage species are growing can stimulate diverse grasses, improve nutrient cycling, and promote livestock health. Agroforestry can facilitate water infiltration, reduce soil erosion, and diminish the impacts of droughts. Diversifying livelihoods will allow a broader range of activities to be pursued as well as providing scope for substitutions between asset categories, such as selling livestock in order to buy farming inputs. Embracing these recommendations may significantly reduce vulnerability.

Acknowledgements The author would like to acknowledge the South African Systems Analysis Centre and the funding provided by the National Research Foundation (NRF) and the Department of Science and Technology (DST), South Africa.

Open Access This article is distributed under the terms of the Creative Commons Attribution 4.0 International License (http://crea tivecommons.org/licenses/by/4.0/), which permits unrestricted use, distribution, and reproduction in any medium, provided you give appropriate credit to the original author(s) and the source, provide a link to the Creative Commons license, and indicate if changes were made.

\section{References}

Aboagye, D. 2012. The political ecology of environmental hazards in Accra, Ghana. Journal of Environment and Earth Science 2(10): 2224-3216.

Alasad, R., I. Motawa, and S. Ougunlana. 2013. A System DynamicsBased Model for demand forecasting in PPP infrastructure projects-A case of toll roads. Organization, Technology \& Management in Construction: An International Journal 6(2): 791-798.

Armas, I., and A. Gavriş. 2013. Social vulnerability assessment using spatial multi-criteria analysis (SEVI model) and the Social Vulnerability Index (SoVI model) — A case study for Bucharest, Romania. Natural Hazards and Earth System Sciences 13(6): 1481-1499.

Arnold, R.D., and J.P. Wade. 2015. A definition of systems thinking: A systems approach. Procedia Computer Science 44: 669-678.

Belle, J., S. Moyo, and A.A. Ogundeji. 2017. Assessing communal farmers' preparedness to drought in the Umguza District, Zimbabwe. International Journal of Disaster Risk Reduction 22: 194-203.

Bola, G., C. Mabiza, J. Goldin, K. Kujinga, I. Nhapi, H. Makurira, and D. Mashauri. 2014. Coping with droughts and floods: A case study of Kanyemba, Mbire District, Zimbabwe. Physics and Chemistry of the Earth 67-69: 180-186.

Braun, V., and V. Clarke. 2012. Research designs: Quantitative, qualitative, neuropsychological, and biological: Thematic analysis. In APA handbook of research methods in psychology, ed. H. Cooper, 57-71. Washington, DC: American Psychological Association.

Bryan, E., C. Ringler, B.Okoba, C. Roncoli, S. Silvestri, and M. Herrero. 2013. Adapting agriculture to climate change in Kenya: Household strategies and determinants. Journal of Environmental Management 114: 26-35.

Burns, J.R., and P. Musa. 2001. Structural validation of causal loop diagrams. In Proceedings of the 19th International Conference of the System Dynamics Society, 23-27 July 2001, Atlanta, 
Georgia, USA, ed. J.H. Hines, V.G. Diker, R.S. Langer, and J.I. Rowe. https://www.systemdynamics.org/assets/conferences/ 2001/papers/Burns_1.pdf. Accessed 16 Mar 2019.

Cabrera, D., L. Cabrera, E. Powers, J. Solin, and J. Kushner. 2018. Applying systems thinking models of organizational design and change in community operational research. European Journal of Operational Research 268(3): 932-945.

Castillo-Montoya, M. 2016. Preparing for interview research: The interview protocol refinement framework. The Qualitative Report 21(5): 811-831.

Chen, C., D. Neal, and M. Zhou. 2012. Understanding the evolution of a disaster: A Framework for Assessing Crisis in a System Environment (FACSE). Natural Hazards 65(1): 407-422.

Chikodzi, D., T. Murwendo, and F.M. Simba. 2013. Climate change and variability in Southeast Zimbabwe: Scenarios and societal opportunities. American Journal of Climate Change 2: 36-46.

Chikoore, H., J.H. Vermeulen, and M.R. Jury. 2015. Tropical cyclones in the Mozambique Channel: January-March 2012. Natural Hazards 77(3): 2081-2095.

Cohen, L., L. Manion, and K. Morrison. 2011. Research methods in education, 7th edn. London: Routledge.

Collins, T.W. 2008. The political ecology of hazard vulnerability: Marginalization, facilitation and the production of differential risk to urban wildfires in Arizona's White Mountains. Journal of Political Ecology 15: 21-43.

Coulibaly, J.Y., G.A. Gbetibouo, G. Kundhlande, G.W. Sileshi, and T.L. Beedy. 2015. Responding to crop failure: Understanding farmers' coping strategies in Southern Malawi. Sustainability 7(2): 1620-1636.

CRED (Centre for Research on the Epidemiology of Disasters). 2018. EM-DAT (The Emergency Events Database). Country profile database-Zimbabwe. https://www.emdat.be/emdat_db/. Accessed 12 May 2018.

Cutter, S.L., C.T. Emrich, J.J. Webb, and D. Morath. 2009. Social vulnerability to climate variability hazards: A review of the literature. Final report to Oxfam America. Columbia, SC: University of South Carolina.

Dalu, M.T.B., C.M. Shackleton, and T. Dalu. 2018. Influence of land cover, proximity to streams and household topographical location on flooding impact in informal settlements in the Eastern Cape, South Africa. International Journal of Disaster Risk Reduction 28: 481-490.

DCP (Department of Civil Protection). 2007. Situation report on Chadereka flooding incident. Harare. http://www.drmzim.org. zw. Accessed 16 Jun 2018.

DCP (Department of Civil Protection). 2013. Situation report number 4 of 2013: Rainfall season SADC SARCOF update Zimbabwe national outlook. Harare. http://www.drmzim.org.zw. Accessed 16 Jun 2018.

DCP (Department of Civil Protection). 2015. Topical issues about Zimbabwe's disaster risk profile. Harare. http://www.drmzim. org.Zw. Accessed 16 Jun 2018.

de Visser, J., N. Steytler, and N. Machingauta (eds.). 2010. Local government reform in Zimbabwe: A policy dialogue. Cape Town: Community Law Centre, University of the Western Cape.

Domenech, J., T. Eveleigh, and B. Tanju. 2018. Marine Hydrokinetic (MHK) Systems: Using systems thinking in resource characterization and estimating costs for the practical harvest of electricity from tidal currents. Renewable \& Sustainable Energy Reviews 81: 723-370.

Douglas, I. 2017. Flooding in African cities, scales of causes, teleconnections, risks, vulnerability and impacts. International Journal of Disaster Risk Reduction 26: 34-42.

Dube, E., O. Mtapuri, and J. Matunhu. 2018. Flooding and poverty: Two interrelated social problems impacting rural development in
Tsholotsho district of Matabeleland North province in Zimbabwe. Jàmbá: Journal of Disaster Risk Studies 10(1): 1-7.

Finch, C., C.T. Emrich, and S.L. Cutter. 2010. Disaster disparities and differential recovery in New Orleans. Population and Environment 31(4): 179-202.

Gain, A.K, V. Mojtahed, C. Biscaro, S. Balbi, and C. Giupponi. 2015. An integrated approach of flood risk assessment in the eastern part of Dhaka City. Natural Hazards 79(3): 1499-1530.

GoZ (Government of Zimbabwe). 2015. Decent work country programme for Zimbabwe 2012-2015. Harare: GoZ.

Guvamombe, I. 2011. Flood hit Muzarabani. The Herald, 18 February 2011. https://www.herald.co.zw/. Accessed 26 Jul 2015.

Hanjra, M.A., T. Ferede, and D.G. Gutta. 2009a. Reducing poverty in sub-Saharan Africa through investments in water and other priorities. Agricultural Water Management 96(7): 1062-1070.

Hanjra, M.A., T. Ferede, and D.G. Gutta. 2009b. Pathways to breaking the poverty trap in Ethiopia: Investments in agricultural water, education, and markets. Agricultural Water Management 96(11): 1596-1604.

Hewitt, K. 2013. Environmental disasters in social context: Toward a preventive and precautionary approach. Natural Hazards 66(1): 3-14.

Jiri, O., and P.L. Mafongoya. 2018. Managing vulnerability to drought and enhancing smallholder farmers resilience to climate change risks in Zimbabwe. In Handbook of climate change resilience, ed. W. Leal Filho, 1-17. New York: Springer.

Kapp, J.M., E.J. Simoes, A. Debiasi, and S.J. Kravet. 2017. A conceptual framework for a systems thinking approach to US population health. Systems Research and Behavioral Science 34(6): 686-698.

Kelman, I., J.C. Gaillard, J. Lewis, and J. Mercer. 2016. Learning from the history of disaster vulnerability and resilience research and practice for climate change. Natural Hazards 82(S1): 129-143.

Kenny, C. 2012. Disaster risk reduction in developing countries: Costs, benefits and institutions. Disasters 36(4): 559-588.

Khazai, B., T. Kunz-Plapp, C. Büscher, and A. Wegner. 2014. VuWiki: An ontology-based semantic Wiki for vulnerability assessments. International Journal of Disaster Risk Science 5(1): $55-73$.

Klein, R.J.T., G.F. Midgley, B.L. Preston, M. Alam, F.G.H. Berkhout, K. Dow, and M.R. Shaw. 2014. Adaptation opportunities, constraints, and limits. In Assessment Report 5-Climate change 2014: Impacts, adaptation, and vulnerability. Part A: Global and sectoral aspects, 899-943. Cambridge: Cambridge University Press.

Kolen, B., and I. Helsloot. 2014. Decision-making and evacuation planning for flood risk management in the Netherlands. Disasters 38(3): 610-635.

Kusenbach, M., J.L. Simms, and G.A. Tobin. 2010. Disaster vulnerability and evacuation readiness: Coastal mobile home residents in Florida. Natural Hazards 52(1): 79-95.

Lane, D.C., E. Munro, and E. Husemann. 2016. Blending systems thinking approaches for organisational analysis: Reviewing child protection in England. European Journal of Operational Research 251(1): 613-623.

Lich, K.H., J.B. Urban, L. Frerichs, and G. Dave. 2017. Extending systems thinking in planning and evaluation using group concept mapping and system dynamics to tackle complex problems. Evaluation and Program Planning 60: 254-264.

Liu, Z., and J. Lan. 2015. The sloping land conversion program in China: Effect on the livelihood diversification of rural households. World Development 70: 147-161.

Mabuku, M.P., A. Senzanje, M. Mudhara, G. Jewitt, and W. Mulwafu. 2018. Rural households' flood preparedness and social determinants in Mwandi district of Zambia and Eastern Zambezi 
Region of Namibia. International Journal of Disaster Risk Reduction 28: 284-297.

Makuvaro, V., C.T.F. Murewi, J. Dimes, and I. Chagonda. 2018. Are smallholder farmers' perceptions of climate variability and change supported by climate records? A case study of lower Gweru in semiarid central Zimbabwe. Weather, Climate, and Society 10(1): $35-49$

Mashizha, T.M., M. Monga, and M.A. Dzvimbo. 2017. Improving livelihoods of resettled farmers through development of a knowledge base on climate change in Mhondoro-Ngezi District, Zimbabwe. International Journal of Sustainable Development Research 3(2): 18-26.

Masunungure, C., and S.E. Shackleton. 2018. Exploring long-term livelihood and landscape change in two semi-arid sites in Southern Africa: Drivers and consequences for social-ecological vulnerability. Land 7(50): 1-23.

Mavhura, E. 2017. Applying a systems-thinking approach to community resilience analysis using rural livelihoods: The case of Muzarabani District, Zimbabwe. International Journal of Disaster Risk Reduction 25: 248-258.

Mavhura, E. 2018. Analysing drivers of vulnerability to flooding: A systems approach. South African Geographical Journal 101(1): 72-90.

Mavhura, E., A. Collins, and P.P. Bongo. 2017. Flood vulnerability and relocation readiness in Zimbabwe. Disaster Prevention and Management: An International Journal 26(1): 41-54.

Mavhura, E., B. Manyena, and A.E. Collins. 2017. An approach for measuring social vulnerability in context: The case of flood hazards in Muzarabani district, Zimbabwe. Geoforum 86: 103-117.

Mock, N., C. Béné, M. Constas, and T. Frankenberger. 2015. Systems analysis in the context of resilience. Technical series No. 6. Rome: Resilience Measurement Technical Working Group.

Molderez, I., and K. Ceulemans. 2018. The power of art to foster systems thinking, one of the key competencies of education for sustainable development. Journal of Cleaner Production 186: $758-770$.

Muhonda, P., C. Mabiza, H. Makurira, K. Kujinga, I. Nhapi, J. Goldin, and D.A. Mashauri. 2014. Analysis of institutional mechanisms that support community response to impacts of floods in the middle-zambezi river basin, Zimbabwe. Physics and Chemistry of the Earth 76-78: 64-71.

Mukherjee, M., and K. Takara. 2018. Urban green space as a countermeasure to increasing urban risk and the UGS-3CC resilience framework. International Journal of Disaster Risk Reduction 28: 854-861.

Muzamhindo, N., S. Mtabheni, O. Jiri, E. Mwakiwa, and B. HanyaniMlambo. 2015. Factors influencing smallholder farmers' adaptation to climate change and variability in Chiredzi district of Zimbabwe. Journal of Economics and Sustainable Development 6(9): 1-9.

Ndah, B.A., and O.J. Odihi. 2017. A systematic study of disaster risk in Brunei Darussalam and options for vulnerability-based disaster risk reduction. International Journal of Disaster Risk Science 8(2): 208-223.

Ndhlovu, L. 2018. Drought-threatened Zimbabwe faces a quandary: Grow maize or not? https://www.preventionweb.net/news/view/ 62188. Accessed 29 Nov 2018.

Puertas, D.G., F. van Steenbergen, A.M. Haile, M. Kool, and T.G. Embaye. 2015. Flood based farming systems in Africa. Spate Irrigation Network. http://spate-irrigation.org/wp-content/ uploads/2015/03/OP5_Flood-based-farming-in-Africa_SF.pdf. Accessed 17 Jun $201 \overline{6}$.

Raschky, P.A. 2008. Institutions and the losses from natural disasters. Natural Hazards and Earth System Sciences 8(4): 627-634.
Roberts, M.E., B.M. Stewart, D. Tingley, C. Lucas, J. Leder-luis, S.K. Gadarian, B. Albertson, and D.G. Rand. 2014. Structural topic models for open-ended survey responses. American Journal of Political Science 58(4): 1064-1082.

Rufat, S., E. Tate, C.G. Burton, and A.S. Maroof. 2015. Social vulnerability to floods: Review of case studies and implications for measurement. International Journal of Disaster Risk Reduction 14: 470-486.

Rurinda, J., P. Mapfumo, M.T. Van Wijk, F. Mtambanengwe, M.C. Rufino, R. Chikowo, and K.E. Giller. 2014. Sources of vulnerability to a variable and changing climate among smallholder households in Zimbabwe: A participatory analysis. Climate Risk Management 3: 65-78.

Rurinda, J., M.T. Van Wijk, P. Mapfumo, K. Descheemaeker, I. Supit, and K.E. Giller. 2015. Climate change and maize yield in southern Africa: What can farm management do? Global Change Biology 21(12): 4588-4601.

Saunders, B., J. Sim, T. Kingstone, S. Baker, J. Waterfield, B. Bartlam, H. Burroughs, and C. Jinks. 2018. Saturation in qualitative research: Exploring its conceptualization and operationalization. Quality and Quantity 52(4): 1893-1907.

Shiferaw, B., K. Tesfaye, M. Kassie, T. Abate, B.M. Prasanna, and A. Menkir. 2014. Managing vulnerability to drought and enhancing livelihood resilience in sub-Saharan Africa: Technological, institutional and policy options. Weather and Climate Extremes 3: 67-79.

Shinn, J.E., B. King, K.R. Young, and K.A. Crews. 2014. Variable adaptations: Micro-politics of environmental displacement in the Okavango Delta, Botswana. Geoforum 57: 21-29.

Shreve, C.M., and I. Kelman. 2014. Does mitigation save? Reviewing cost-benefit analyses of disaster risk reduction. International Journal of Disaster Risk Reduction 10: 213-235.

Siagian, T.H., P. Purhadi, S. Suhartono, and H. Ritonga. 2014. Social vulnerability to natural hazards in Indonesia: Driving factors and policy implications. Natural Hazards 70(2): 1603-1617.

Silverman, D. 2013. Doing qualitative research, 4th edn. London: Sage Publications.

Spear, D., E. Haimbili, M. Angula, M. Baudoin, S. Hegga, M. Zaroug, and A. Okeyo. 2018. Vulnerability and adaptation to climate change in the semi-arid regions of Southern Africa. Ottawa: Collaborative Adaptation Research Initiative in Africa and Asia.

Tetuan, T., R. Ohm, L. Kinzie, S. Mcmaster, B. Moffitt, and M. Mosier. 2017. Does systems thinking improve the perception of safety culture and patient safety? Journal of Nursing Regulation $8(2): 31-39$

Tombindo, F., and T.J. Chirau. 2017. Livelihoods diversification among riverbed farmers: A case study of Nyaminyami district, Zimbabwe. Educor Multidisciplinary Journal 1(1): 113-140.

UNDP (United Nations Development Programme). 2014. UNDP Human development report 2014: Sustaining human progress: Reducing vulnerabilities and building resilience. New York: UNDP. http://hdr.undp.org/en/2014-report/download. Accessed 15 Jun 2018.

UNDP (United Nations Development Programme). 2016. Mapping of selected harzards affecting rural livelihoods in Zimbabwe: A district and ward analysis. http://www.zw.undp.org/content/dam/ zimbabwe/docs/Poverty\%20Reduction/UNDP_ZW_POV_ Hazard-mapping.pdf. Accessed 16 Jun 2018.

UNISDR (United Nations International Strategy for Disaster Reduction). 2004. Terminology: Basic terms on disaster risk reduction. Geneva: UNISDR.

United Nations. 2016. Report of the open-ended intergovernmental expert working group on indicators and terminology relating to disaster risk reduction. Geneva: United Nations.

Usamah, M., J. Handmer, D. Mitchell, and I. Ahmed. 2014. Can the vulnerable be resilient? Co-existence of vulnerability and 
disaster resilience: Informal settlements in the Philippines. International Journal of Disaster Risk Reduction 10: 178-189.

Vaismoradi, M., J. Jones, H. Turunen, and S. Snelgrove. 2016. Theme development in qualitative content analysis and thematic analysis. Journal of Nursing Education and Practice 6(5): 100-110.

Wei, Y., S. Wang, Y. Fang, and Z. Nawaz. 2017. Integrated assessment on the vulnerability of animal husbandry to snow disasters under climate change in the Qinghai-Tibetan Plateau. Global and Planetary Change 157: 139-152.

Wilhelmi, O.V., and R.E. Morss. 2013. Integrated analysis of societal vulnerability in an extreme precipitation event: A Fort Collins case study. Environmental Science \& Policy 26: 49-62.
Wisner, B., T. Cannon, P. Blaikie, and I. Davis, 2004. At risk: Natural hazards, People's vulnerability and disasters, 2nd edn. London: Routledge.

Zaehringer, J.G., G. Wambugu, B. Kiteme, and S. Eckert. 2018. How do large-scale agricultural investments affect land use and the environment on the western slopes of Mount Kenya? Empirical evidence based on small-scale farmers' perceptions and remote sensing. Journal of Environmental Management 213: 79-89.

ZimStat. 2012. Zimbabwe Population Census Report: 2012. Harare: Zimbabwe National Statistical Agency. 